\title{
Development of Transit Bus Idling Control Strategies Using Geospatial Information
}

\author{
Sangjun Park and Myeong-Hun Jeong ${ }^{*}$ \\ Department of Civil Engineering, Chosun University, \\ 309 Pilmoondaero, Dong-gu, Gwangju 61452, South Korea
}

(Received August 19, 2019; accepted October 7, 2019)

Keywords: transit bus, idling, geospatial information, control strategy, fuel consumption

Unnecessary fuel consumption and vehicle emissions due to transit bus idling increase local government subsidies provided to bus companies in South Korea and negatively affect citizen health. In this study, we analyzed the temporal and spatial distributions of transit bus idling using transit bus operational information collected via a digital tachograph. Transit bus management strategies were then proposed on the basis of analytical results. Specifically, all idling times were calculated by analyzing the driving records of all buses operating in Gwangju for 1 day on weekdays, and the idling data were classified into depot, bus stop, and road datasets on the basis of the idling occurrence location. The classified datasets were used to analyze the idling characteristics and fuel consumption, and $\mathrm{CO}_{2}, \mathrm{THC}, \mathrm{CO}$, and $\mathrm{NO}_{x}$ emissions were calculated using the MOtor Vehicle Emission Simulator (MOVES) model. The results show that the largest proportion of total idling time is idling caused by the traffic situation on roads, accounting for $74-81 \%$ of the total. However, $12-18 \%$ of the total idling occurred at bus stops and $4-14 \%$ of the total idling occurred in depots. The compressed natural gas consumed by all transit buses during idling for a single day was $7402 \mathrm{~m}^{3}$, which was estimated to cost approximately $\$ 4585$.

\section{Introduction}

As energy consumption increases worldwide, resulting in global warming and frequent abnormal weather events, efforts are being made to reduce the use of fossil fuels in all areas and protect the environment. In particular, the transportation sector has been highly dependent on fossil fuels and has developed various strategies to improve the eco-friendliness of the system. Representative strategies include increasing the market share of eco-friendly vehicles, such as hybrid and electric vehicles, and reducing passenger car demand by improving the efficiency and mobility of public transportation systems.

Particularly in South Korea, because transit buses are a key component of the public transportation system in local cities, local governments provide subsidies to bus companies to guarantee profits while actively participating in bus routes and operational management. In

*Corresponding author: e-mail: mhjeong@chosun.ac.kr https://doi.org/10.18494/SAM.2019.2557 
particular, local governments are making great efforts to improve their transit bus systems in terms of efficiency and environment to save costs and reduce the adverse effects caused by vehicle emissions. Factors affecting the eco-friendliness of transit bus systems include driving characteristics along with vehicle physical characteristics. In particular, driving characteristics are determined by the factors influencing various driving behaviors that change in time and space. Representative factors include the route length, the number of bus stops, the number of intersections, and the traffic flow congestion level. Idling of transit buses occurs on roads, at bus stops, and at depots caused by traffic congestion, passenger service, and maintenance. Unnecessary fuel consumption and vehicle emissions due to transit bus idling increase local government subsidies and negatively affect citizen health. A recent study analyzed impact factors affecting bus fuel consumption using the classification and regression tree model. ${ }^{(1)}$ In this study, the frequency of idling was analyzed as one of the factors sensitive to fuel consumption.

In terms of research trends related to bus idling, many studies have been conducted to analyze the pollutant emission characteristics of school or public transit buses and investigate their effects on passengers. For example, a study was conducted to investigate the characteristics of fine particles and gaseous emissions generated during idling by school buses in the northeastern U.S. ${ }^{(2)}$ The concentrations of ultrafine particles around an idling school bus were analyzed in another study. ${ }^{(3)}$ There have been some studies that investigated the characteristics of pollutants emitted during idling when eco-friendly fuel was used. Particulate matter (PM) emission characteristics of public transit buses using B20 (20\% biodiesel and 80\% ultralow sulfur diesel) fuel were studied. ${ }^{(4)}$ The characteristics of vehicle emissions because of idling of diesel heavy-duty vehicles (trucks + buses) and compressed natural gas (CNG) heavy-duty vehicles were compared. ${ }^{(5)}$ The PM emission characteristics of transit buses using alternative fuels were analyzed. ${ }^{(6)}$ In addition, many studies have been conducted to analyze idling prevention technologies or policies applicable to transit buses and their effects. For example, a simulation analysis was conducted to analyze the fuel savings effect when an idling stop and go (ISG) system was applied to a transit bus. ${ }^{(7)}$ The control strategies of various energy-saving means were studied and the effects were verified using a hardware-in-theloop simulation platform. ${ }^{(8)}$ Another study reviewed the causes and effects of bus idling and evaluated the potential benefits and costs of using idling reduction technologies. ${ }^{(9)}$ A study evaluated the restriction on idling vehicles to lower PM2.5 levels at busy bus stations. ${ }^{(10)}$

As previously described, previous studies have focused on analyzing the characteristics of vehicle emissions during idling or the effects of applying ISG systems to transit buses. It is difficult to find studies aimed to establish traffic management strategies that mitigate the adverse effects of transit bus idling based on temporal and spatial frequencies and the density of idling resulting from the use of spatial information through a literature review. Therefore, the objectives of this study were to analyze the temporal and spatial distributions of transit bus idling using transit bus operational information collected using a digital tachograph (DTG) and to derive potentially applicable transit bus management strategies according to the results obtained through a case analysis of Gwangju, South Korea. 


\section{Analysis Methodologies and Fuel Consumption Estimation}

In this study, we utilized DTG data collected from transit buses operating in Gwangju to analyze idling characteristics. In this section, we briefly provide the characteristics of DTG data and describe the fuel consumption estimation method to estimate the amount of fuel consumed during idling. In addition, the transit bus system of Gwangju is explained to provide background information of the transit bus system.

\subsection{Digital tachograph}

The development of information and communication technology has resulted in various types of big data and their applications. The term big data is defined as data sets that are too large or complex to be manipulated using traditional methodologies. The transportation sector is believed to be among the relevant areas utilizing big data to improve the quality of transportation systems. In this context, it is mandatory to install DTGs in vehicles such as taxis, commercial trucks, and buses including transit buses to improve the safety of the transportation system in South Korea. The driving records of these vehicles start to be recorded at a $1 \mathrm{~s}$ resolution when power is supplied to the DTG installed in the vehicle, and recording is stopped when the power is turned off. Specifically, the vehicle speed, engine speed, breaking status, latitude, longitude, heading, and latitudinal and longitudinal accelerations are recorded every second. ${ }^{(11)}$

To analyze the characteristics of transit bus idling behavior, in this study, we utilized historical driving data collected on June 15 (Monday), 2015, in Gwangju, South Korea. The total number of DTG files collected was 689. All the information recorded from the beginning to the end of the operation of a transit bus during a single day is contained in a DTG file. Note that the recording is active even though the engine is turned off if the DTG is turned on. Therefore, the data recorded when the engine is turned off were excluded from the datasets. In addition, invalid data not having the latitude and longitude were excluded. For illustration purposes, a public transit bus trip is shown on Google Maps ${ }^{(12)}$ using its speed and location profile recorded from the DTG as shown in Fig. 1(a). Specifically, the height of the line extruded indicates its speed profile recorded from the DTG. Because the line in Fig. 1(a) is exactly identical to the route of the Suwan-12 transit bus shown in Fig. 1(b), ${ }^{(13)}$ it was found to be a Suwan-12 transit bus. From the DTG file, it was found that the total travel and idling times were 5916 and 2527 s, respectively.

\subsection{Fuel consumption modeling}

To estimate the fuel consumption rate during transit bus idling, in this study, we utilized the MOVES model developed by the United States Environmental Protection Agency. The MOtor Vehicle Emission Simulator (MOVES) model provides various vehicle types for the estimation of fuel consumption and exhaust emissions. In this study, we utilized the vehicle type "Transit Bus." (14) Specifically, the energy consumption rates in units of kilojoules (kJ), 


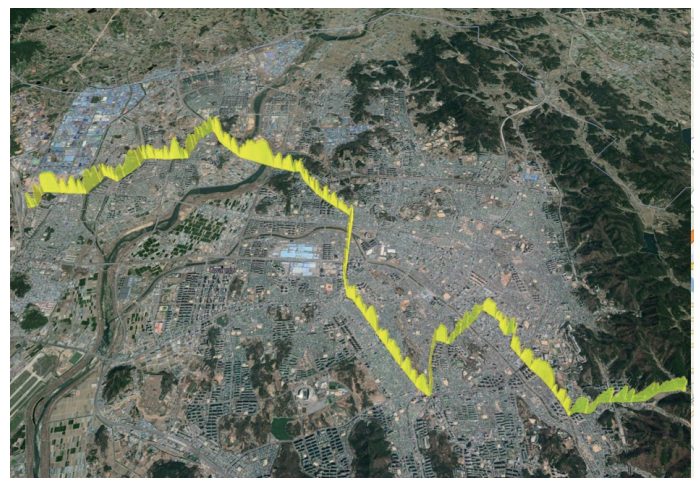

(a)

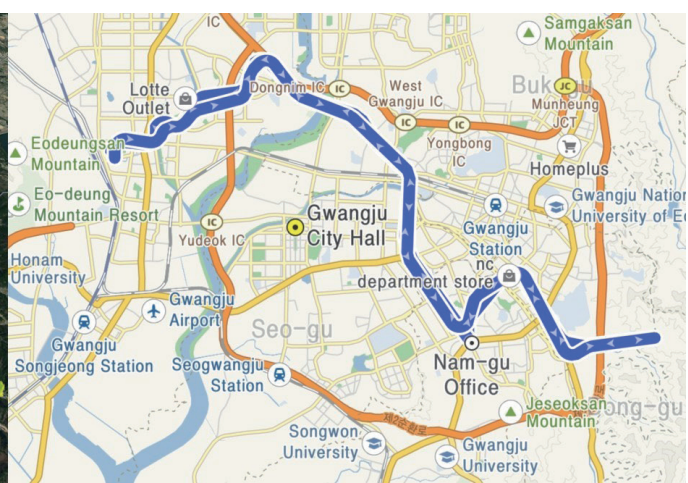

(b)

Fig. 1. (Color online) (a) DTG sample (Google Maps) and (b) route of Suwan-12 transit bus.

the total hydrocarbon content (THC), and carbon monoxide (CO), nitrogen oxide $\left(\mathrm{NO}_{x}\right)$, and carbon dioxide $\left(\mathrm{CO}_{2}\right)$ emissions in units of grams $(\mathrm{g})$ were extracted from the MOVES database on the basis of the operating condition bin (designated OpModes), which is determined by the vehicle speed and specific power. The OpMode for idling was selected from the 23 OpModes of the MOVES model. Because most of the transit buses operating in Gwangju use compressed natural gas $(\mathrm{CNG})$, the energy consumption in $\mathrm{kJ}$ was converted to $\mathrm{CNG}$ in $\mathrm{m}^{3}$ given that $1 \mathrm{~m}^{3}$ of CNG is equivalent to $42.59 \mathrm{MJ}$. Table 1 shows the energy consumption and emission rates for transit bus idling estimated from the MOVES model.

\subsection{Gwangju transit bus system and analysis methodologies}

Gwangju, the sixth largest city in South Korea, is a metropolitan city in South Jeolla. The population of Gwangju was 1502881 in 2015 and it has an area of $501 \mathrm{~km}^{2}$. $^{(15)}$ The public transit bus system of Gwangju consisted of 1054 buses with 105 bus routes. The quasi-public bus operation system, which means that bus companies are privately owned but are regulated by the government, was introduced in 2006. In this system, the city council can manage the bus lines to improve the quality of the bus system but must provide subsidies to participating bus companies depending on the cost of the deficit. The cost of the subsidy is determined by the total operating costs dominated by labor and fuel use costs and revenue. Similar to other municipalities, Gwangju strives to lower the total operating cost by improving the fuel economy of operating buses.

To analyze the characteristics of transit bus idling, the following procedure was applied in this study. First, we used the DTG data to calculate the occurrence time, duration, and location of individual idling, and to prepare a dataset by accumulating all idling data. Idling for longer than $10 \mathrm{~s}$ was extracted from the dataset because it was reported that idling for longer than $10 \mathrm{~s}$ uses more fuel and emits more $\mathrm{CO}_{2}$ than engine restarting. ${ }^{(16)}$ The dataset was then divided into three categories on the basis of the location of the idling occurrence.

The first type of idling occurs when a transit bus is waiting for the next operation in the bus depot. In the case of Gwangju, as shown in Fig. 2(a), a total of eight public bus depots are in 
Table 1

Energy consumption and emissions rates for transit bus idling.

\begin{tabular}{ccccc}
\hline $\mathrm{CO}_{2}(\mathrm{~g} / \mathrm{s})$ & $\mathrm{THC}(\mathrm{g} / \mathrm{s})$ & $\mathrm{CO}(\mathrm{g} / \mathrm{s})$ & $\mathrm{NO}_{x}(\mathrm{~g} / \mathrm{s})$ & Energy $(\mathrm{kJ} / \mathrm{s})$ \\
2.12 & 0.00034 & 0.00116 & 0.00289 & 29.56 \\
\hline
\end{tabular}

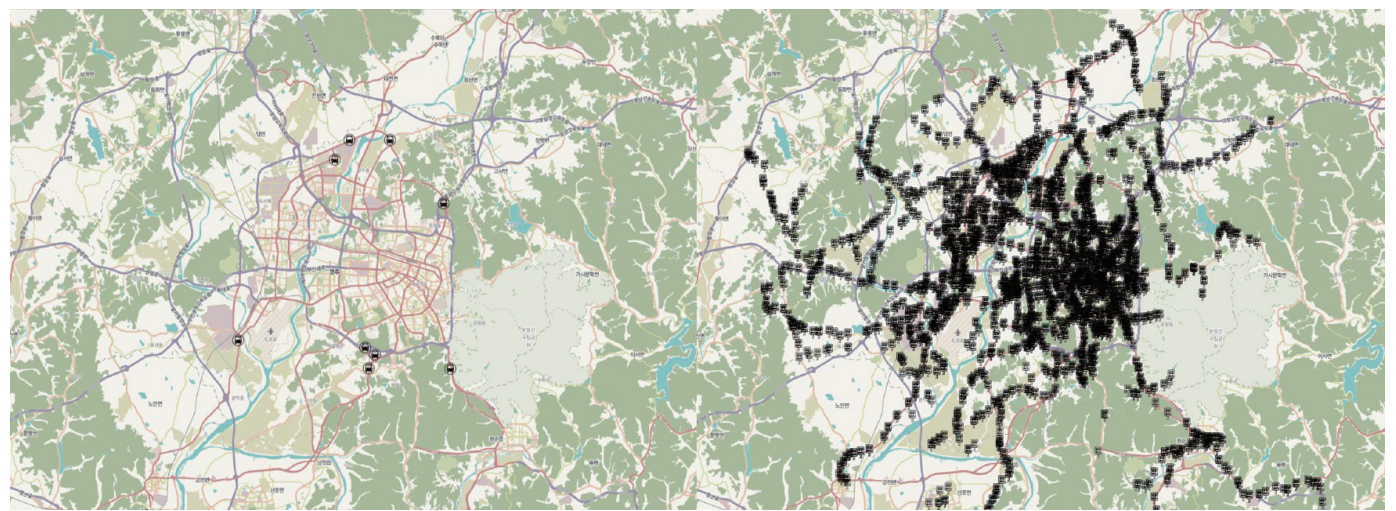

(a)

(b)

Fig. 2. (Color online) (a) Bus depots and (b) bus stops.

operation. The average radius of all the depots was calculated as $45 \mathrm{~m}$. Therefore, idling was classified as this type if the distance between depots is less than $45 \mathrm{~m}$. The second type of idling occurs when a transit bus is waiting to pick up and drop off passengers at bus stops. As shown in Fig. 2(b), there are bus stops throughout Gwangju. A total of 2740 bus stops are in operation in Gwangju. A typical bus stop on the roadside is approximately $45 \mathrm{~m}$ in length: $15 \mathrm{~m}$ for deceleration, $15 \mathrm{~m}$ for one bus stop, and $15 \mathrm{~m}$ for acceleration. Therefore, if the distance to the nearest bus stop is less than $23 \mathrm{~m}$, it was classified as the second type of idling. Finally, idling that did not occur at depots or bus stops was considered to occur under a traffic condition affected by the congestion level or traffic signal status. Given the three idling datasets, the temporal and spatial distributions of idling were investigated to establish transit bus idling control strategies and assess their effects as described in the following section.

\section{Spatial and Temporal Analyses of Transit Bus Idling}

\subsection{Characteristics of transit bus idling}

Prior to the analysis, idling that occurred between 0:00 and 4:00 am was regarded as abnormal operation and excluded from the dataset. From the analysis results, it can be seen that idling significantly occurs during the morning peak and evening peak times as clearly shown in Fig. 3(a). Specifically, as shown in Table 2, the number of idling occurrences was the highest at 12867 at 8:00-9:00 am followed by 12257 at 6:00-7:00 pm. This is because traffic congestion increases and more passengers attempt to use transit buses during peak times. However, in the case of depots, it seems that the most idling occurred while waiting for a long time to prepare for the first operation at 4:00-6:00 am. In addition, it seems that idling frequently occurred while waiting at depots after the end of the operation. 


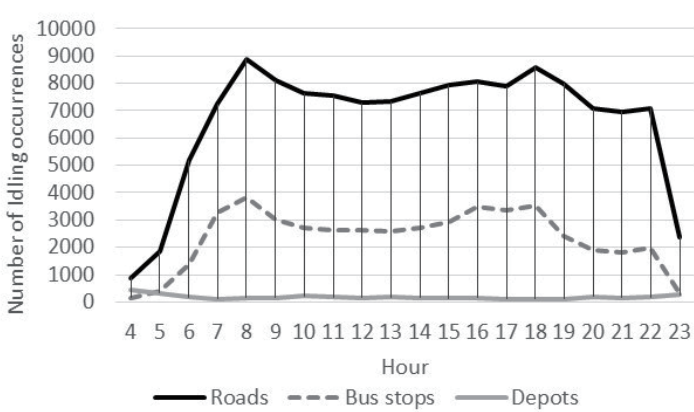

(a)

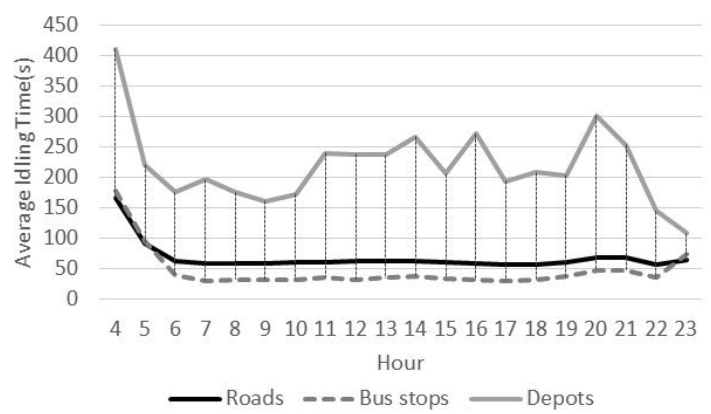

(b)

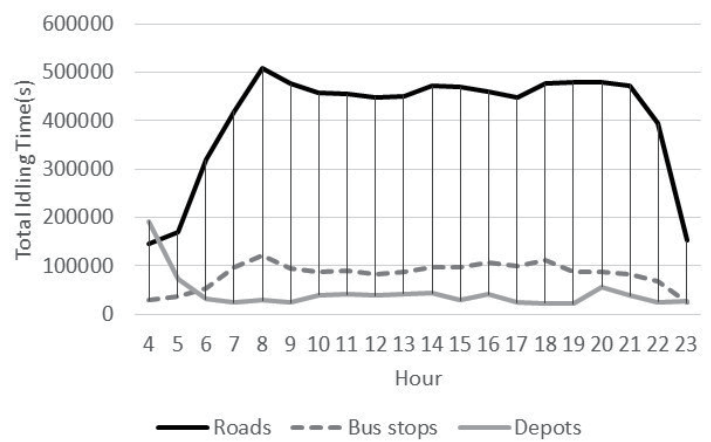

(c)

Fig. 3. (a) Number of idling occurrences, (b) average idling time(s), and (c) total idling time(s).

Table 2

Idling characteristics of transit buses by time of day.

\begin{tabular}{rrrrrrrrrr}
\hline \multirow{2}{*}{$\begin{array}{l}\text { Time } \\
\text { (h) }\end{array}$} & \multicolumn{3}{c}{ Total idling time (s) } & \multicolumn{3}{c}{ Number of idling occurrences } & \multicolumn{3}{c}{ Average idling time (s) } \\
\cline { 2 - 9 } $4-5$ & Roads & Bus stops & Depots & Roads & Bus stops & Depots & Roads & Bus stops & Depots \\
\hline $5-6$ & 169143 & 29136 & 192402 & 877 & 164 & 468 & 166 & 178 & 411 \\
$6-7$ & 319246 & 54584 & 31047 & 5182 & 1382 & 177 & 62 & 39 & 175 \\
$7-8$ & 419581 & 97446 & 24147 & 7242 & 3257 & 123 & 58 & 30 & 196 \\
$8-9$ & 509122 & 120376 & 28833 & 8886 & 3816 & 165 & 57 & 32 & 175 \\
$9-10$ & 475926 & 95624 & 24813 & 8103 & 2999 & 154 & 59 & 32 & 161 \\
$10-11$ & 456919 & 87047 & 39479 & 7623 & 2711 & 229 & 60 & 32 & 172 \\
$11-12$ & 454656 & 89760 & 40688 & 7543 & 2619 & 170 & 60 & 34 & 239 \\
$12-13$ & 448426 & 83397 & 38487 & 7289 & 2640 & 162 & 62 & 32 & 238 \\
$13-14$ & 451203 & 88738 & 42068 & 7318 & 2569 & 178 & 62 & 35 & 236 \\
$14-15$ & 471251 & 97504 & 43206 & 7650 & 2700 & 162 & 62 & 36 & 267 \\
$15-16$ & 469345 & 98004 & 28863 & 7917 & 2934 & 140 & 59 & 33 & 206 \\
$16-17$ & 460884 & 107936 & 41032 & 8046 & 3493 & 151 & 57 & 31 & 272 \\
$17-18$ & 447065 & 98870 & 24127 & 7892 & 3338 & 125 & 57 & 30 & 193 \\
$18-19$ & 476888 & 110713 & 23501 & 8594 & 3550 & 113 & 55 & 31 & 208 \\
$19-20$ & 478143 & 88362 & 21731 & 7991 & 2421 & 107 & 60 & 36 & 203 \\
$20-21$ & 478336 & 88909 & 57464 & 7068 & 1899 & 191 & 68 & 47 & 301 \\
$21-22$ & 472106 & 82961 & 38471 & 6961 & 1814 & 152 & 68 & 46 & 253 \\
$22-23$ & 394214 & 68070 & 25391 & 7100 & 1974 & 176 & 56 & 34 & 144 \\
$23-24$ & 152354 & 24197 & 28097 & 2390 & 326 & 260 & 64 & 74 & 108 \\
\hline
\end{tabular}


As shown in Fig. 3(b), the idling that occurred at 4:00-6:00 am was relatively long compared with that during other time periods regardless of idling type. This was caused not only by idling occurring at depots but also by buses waiting for their first operation on roads and at bus stops. Also shown in Fig. 3(b) is that buses idle in depots for a significantly longer period of time than on roads or at bus stops. Specifically, the buses analyzed had an idling time of 5 min or longer on average during the morning; it was shown that it is necessary to induce idling prevention during the morning, particularly in depots. The idling pattern of buses in depots is irregular, while the idling times on roads or at bus stops are relatively similar. An unexpected situation was relatively long idling occurring at 8:00-10:00 pm during the evening.

The longest total idling time, which is the product of the total number of idling occurrences and the average idling time, was calculated as $183 \mathrm{~h}$ during the morning peak period of 8:00-9:00 am. The second longest idling time was calculated as approximately $174 \mathrm{~h}$ from 8:00 to 9:00 pm. The largest proportion of the total idling time was idling caused by the traffic situation on roads, accounting for $74-81 \%$ of the total. However, $12-18 \%$ of the total idling occurred at bus stops and $4-14 \%$ of the total idling occurred in depots.

\subsection{Fuel consumption and exhaust emissions}

Table 3 shows the CNG consumption, CNG costs, and emissions of transit buses caused by idling. The CNG consumed by all transit buses during idling for a single day was $7402 \mathrm{~m}^{3}$,

Table 3

Fuel uses and exhaust emissions resulting from transit bus idling by time of day.

\begin{tabular}{|c|c|c|c|c|c|c|}
\hline \multirow[b]{2}{*}{$\begin{array}{l}\text { Time } \\
\text { (h) }\end{array}$} & \multicolumn{2}{|c|}{ Fuel uses } & \multicolumn{4}{|c|}{ Exhaust emissions } \\
\hline & $\begin{array}{c}\mathrm{CNG} \\
\text { consumption }\left(\mathrm{m}^{3}\right)\end{array}$ & $\begin{array}{c}\mathrm{CNG} \\
\text { (US dollar) }\end{array}$ & $\mathrm{CO}_{2}(\mathrm{~kg})$ & THC (g) & $\mathrm{CO}(\mathrm{g})$ & $\mathrm{NO}_{x}(\mathrm{~g})$ \\
\hline $4-5$ & 255 & 158 & 779 & 123 & 425 & 1061 \\
\hline $5-6$ & 194 & 120 & 594 & 94 & 324 & 809 \\
\hline $6-7$ & 281 & 174 & 860 & 136 & 469 & 1171 \\
\hline $7-8$ & 376 & 233 & 1150 & 182 & 627 & 1566 \\
\hline $8-9$ & 457 & 283 & 1398 & 221 & 763 & 1905 \\
\hline $9-10$ & 414 & 256 & 1267 & 200 & 691 & 1725 \\
\hline $10-11$ & 405 & 251 & 1239 & 196 & 676 & 1688 \\
\hline $11-12$ & 406 & 252 & 1243 & 196 & 678 & 1693 \\
\hline $12-13$ & 396 & 245 & 1211 & 191 & 661 & 1650 \\
\hline $13-14$ & 404 & 250 & 1236 & 195 & 675 & 1684 \\
\hline $14-15$ & 425 & 263 & 1300 & 205 & 709 & 1770 \\
\hline $15-16$ & 414 & 256 & 1266 & 200 & 691 & 1725 \\
\hline $16-17$ & 423 & 262 & 1295 & 205 & 707 & 1764 \\
\hline $17-18$ & 396 & 245 & 1211 & 191 & 661 & 1649 \\
\hline $18-19$ & 424 & 263 & 1298 & 205 & 708 & 1768 \\
\hline 19-20 & 408 & 253 & 1250 & 197 & 682 & 1702 \\
\hline $20-21$ & 434 & 269 & 1327 & 210 & 724 & 1807 \\
\hline $21-22$ & 412 & 255 & 1261 & 199 & 688 & 1717 \\
\hline $22-23$ & 338 & 210 & 1036 & 164 & 565 & 1411 \\
\hline $23-24$ & 142 & 88 & 435 & 69 & 237 & 592 \\
\hline Total & 7402 & 4585 & 22657 & 3580 & 12366 & 30858 \\
\hline
\end{tabular}


which was estimated to cost approximately $\$ 4585$. The idling patterns of city buses have a close relationship with weather. More idling normally occurs when using the air conditioner (A/C) and heater during summer and winter, respectively. In this study, the data for a weekday in June, which has a $22.5^{\circ} \mathrm{C}$ average temperature, were used. Therefore, the effect of idling using an $\mathrm{A} / \mathrm{C}$ or heater was considered to be minimal. Assuming that the results in Table 3 are representative of the average value of the idling pattern on a weekday, it can be said that the fuel cost caused by idling is approximately 1.7 million dollars per year, a burden of the local government. In addition, there is a social cost to reduce the adverse effects of the exhaust emissions caused by idling. The unit costs of $\mathrm{CO}_{2}, \mathrm{THC}, \mathrm{CO}$, and $\mathrm{NO}_{x}$ emissions were estimated as $\$ 0.04 / \mathrm{kg}, \$ 1.95 / \mathrm{kg}, \$ 0.13 / \mathrm{kg}$, and $\$ 13.28 / \mathrm{kg}$, respectively, in the literature. ${ }^{(17)}$ It is estimated that the social cost is 0.46 million dollars by applying these unit costs.

\section{Development of Transit Bus Idling Control Strategies}

Table 4 shows the analysis results of idling that occurred during the weekday in the depots shown in Fig 2(a). As shown in Table 3, the greatest idling occurred at the Index-1 depot. Specifically, the total number of idling occurrences was 1373 at the Index-1 depot and the average idling time per bus was $212 \mathrm{~s}$, which resulted in idling for $81 \mathrm{~h}$. As a result of utilizing the fuel consumption and emissions rates of the MOVES model in Table 1, $202 \mathrm{~m}^{3}$ of CNG was consumed at the Index-1 depot, which cost $\$ 125$. Assuming that this pattern continues for 1 year, the total CNG cost will be $\$ 45669 /$ year, which is significant. In addition, the resulting $\mathrm{CO}_{2}, \mathrm{THC}, \mathrm{CO}$, and $\mathrm{NO}_{x}$ emissions are $618 \mathrm{~kg}, 98 \mathrm{~g}, 337 \mathrm{~g}$, and $842 \mathrm{~g}$, respectively. Therefore, in terms of traffic management strategy, it is necessary to introduce measures to exclude the cost of fuel that is consumed because of unnecessary idling from the subsidies paid to bus companies, rather than for idling that occurs during maintenance. In addition, it is possible to consider imposing some of the social costs incurred by the exhausted emissions generated by unnecessary fuel consumption.

Then, a spatial analysis was performed to analyze the spatial distribution and density of idling that occurred at bus stops and on roads using the Quantum geographic information system software. First, the area in which idling occurred in Gwangju was divided into grid

Table 4

Idling characteristics, fuel uses, and exhaust emissions of individual depots.

\begin{tabular}{lccccccccc}
\hline \multirow{2}{*}{$\begin{array}{l}\text { Index } \\
\text { of depot }\end{array}$} & \multicolumn{3}{c}{ Idling characteristics } & \multicolumn{3}{c}{ Fuel use } & \multicolumn{3}{c}{ Exhaust emissions } \\
\cline { 2 - 9 } & $\begin{array}{c}\text { Total idling } \\
\text { time }(\mathrm{s})\end{array}$ & $\begin{array}{c}\text { Number of idling } \\
\text { occurrences }\end{array}$ & $\begin{array}{c}\text { Average idling } \\
\text { time }(\mathrm{s})\end{array}$ & $\begin{array}{c}\mathrm{CNG} \\
\left(\mathrm{m}^{3}\right)\end{array}$ & $\begin{array}{c}\text { Cost } \\
(\$)\end{array}$ & $\begin{array}{c}\mathrm{CO}_{2} \\
(\mathrm{~kg})\end{array}$ & $\begin{array}{c}\mathrm{THC} \\
(\mathrm{g})\end{array}$ & $\begin{array}{c}\mathrm{CO} \\
(\mathrm{g})\end{array}$ & $\begin{array}{c}\mathrm{NO}_{x} \\
(\mathrm{~g})\end{array}$ \\
\hline 1 & 291036 & 1373 & 212 & 202 & 125 & 618 & 98 & 337 & 842 \\
2 & 162500 & 664 & 245 & 113 & 70 & 345 & 55 & 188 & 470 \\
3 & 131330 & 455 & 289 & 91 & 56 & 279 & 44 & 152 & 380 \\
4 & 109526 & 435 & 252 & 76 & 47 & 233 & 37 & 127 & 317 \\
5 & 68057 & 350 & 194 & 47 & 29 & 145 & 23 & 79 & 197 \\
6 & 53892 & 171 & 315 & 37 & 23 & 114 & 18 & 62 & 156 \\
7 & 44820 & 228 & 197 & 31 & 19 & 95 & 15 & 52 & 130 \\
8 & 10358 & 34 & 305 & 7 & 4 & 22 & 3 & 12 & 30 \\
9 & 8293 & 42 & 197 & 6 & 4 & 18 & 3 & 10 & 24 \\
\hline
\end{tabular}


cells $1 \mathrm{~km}$ in length and width, and only the cells where idling occurred were extracted from all the cells. Next, the total number of idling occurrences and the total idling time in each cell were calculated. As shown in Fig. 4(a), the total idling time was divided into five categories according to the duration of idling and visualized. Specifically, as shown in Fig. 4(a), darker cells, which have higher saturation, are regions where more idling occurred.

Figure 4(a) shows the distribution and density of idling on the roads showing the distribution from 8:00 to 9:00 am when idling occurred most frequently during the day. As shown in Fig. 4(a), idling occurred from less than $30 \mathrm{~min}$ to $1 \mathrm{~h}$ in many areas but longer than $2 \mathrm{~h}$ in the area slightly to the east from the center, which has a darker color. Figure 4(b) shows the 10 cells where idling occurred the most on the roads. As shown in Fig. 4(b), the number in the cell is the index number indicated in Table 5. As shown in Table 5, the number of idling occurrences was 202 in the Index-1 cell where idling most frequently occurred. The idling time for a bus was $59 \mathrm{~s}$ on average and a total of $3.3 \mathrm{~h}$ of idling occurred during the morning peak in the Index-1 area. A total of $8.2 \mathrm{~m}^{3}$ of $\mathrm{CNG}$ was used for idling in this area, and $\mathrm{CO}_{2}, \mathrm{THC}, \mathrm{CO}$, and $\mathrm{NO}_{x}$ emissions were $25.2 \mathrm{~kg}, 4.0 \mathrm{~g}, 13.7 \mathrm{~g}$, and $34.3 \mathrm{~g}$, respectively. Table 5 shows the idling-related information, fuel consumption, and exhaust emissions of the other areas.

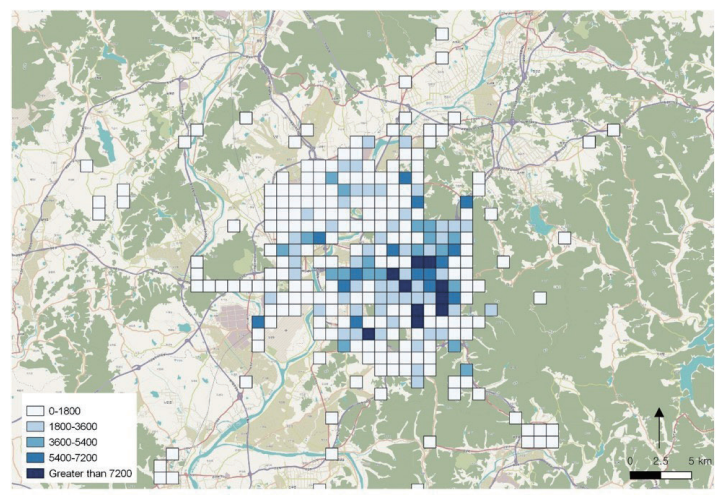

(a)

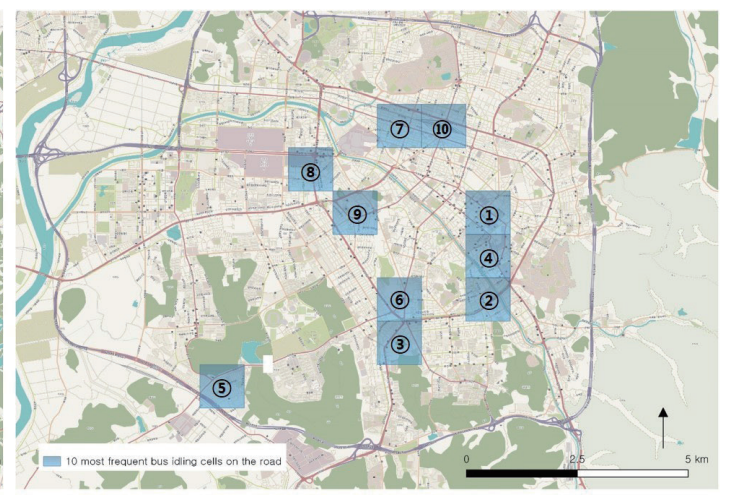

(b)

Fig. 4. (Color online) (a) Distribution and density of idling on roads and (b) 10 frequent idling cells on roads.

Table 5

Idling characteristics, fuel uses, and exhaust emissions of the 10 most frequent idling cells on roads during the morning peak (8:00-9:00 am).

\begin{tabular}{cccccccccc}
\hline \multirow{2}{*}{ Index } & \multicolumn{3}{c}{ Idling characteristics } & \multicolumn{3}{c}{ Fuel use } & \multicolumn{3}{c}{ Exhaust emissions } \\
\cline { 2 - 10 } & $\begin{array}{c}\text { Total idling } \\
\text { time (s) }\end{array}$ & $\begin{array}{c}\text { Number of idling } \\
\text { occurrences }\end{array}$ & $\begin{array}{c}\text { Average idling } \\
\text { time }(\mathrm{s})\end{array}$ & $\begin{array}{c}\mathrm{CNG} \\
\left(\mathrm{m}^{3}\right)\end{array}$ & $\begin{array}{c}\mathrm{Cost} \\
(\$)\end{array}$ & $\begin{array}{c}\mathrm{CO}_{2} \\
(\mathrm{~kg})\end{array}$ & $\begin{array}{c}\mathrm{THC} \\
(\mathrm{g})\end{array}$ & $\begin{array}{c}\mathrm{CO} \\
(\mathrm{g})\end{array}$ & $\begin{array}{c}\mathrm{NO}_{x} \\
(\mathrm{~g})\end{array}$ \\
\hline 1 & 11841 & 202 & 59 & 8.2 & 5.1 & 25.2 & 4.0 & 13.7 & 34.3 \\
2 & 10906 & 180 & 61 & 7.6 & 4.7 & 23.2 & 3.7 & 12.6 & 31.6 \\
3 & 10888 & 206 & 53 & 7.6 & 4.7 & 23.1 & 3.7 & 12.6 & 31.5 \\
4 & 10820 & 189 & 57 & 7.5 & 4.7 & 23.0 & 3.6 & 12.5 & 31.3 \\
5 & 10176 & 158 & 64 & 7.1 & 4.4 & 21.6 & 3.4 & 11.8 & 29.4 \\
6 & 10137 & 163 & 62 & 7.0 & 4.4 & 21.5 & 3.4 & 11.8 & 29.3 \\
7 & 9583 & 123 & 78 & 6.7 & 4.1 & 20.4 & 3.2 & 11.1 & 27.7 \\
8 & 9279 & 178 & 52 & 6.4 & 4.0 & 19.7 & 3.1 & 10.8 & 26.8 \\
9 & 7802 & 117 & 67 & 5.4 & 3.4 & 16.6 & 2.6 & 9.0 & 22.6 \\
10 & 7433 & 110 & 68 & 5.2 & 3.2 & 15.8 & 2.5 & 8.6 & 21.5 \\
\hline
\end{tabular}


As shown in Fig. 4(b), the areas where idling frequently occurs are where major roads pass or intersect (all areas except the Index-5 area are commercial areas) and many activities occur in general. Therefore, it is essential to establish a public transportation management strategy that can reduce unnecessary fuel consumption and exhaust gas emissions caused by idling in the areas where idling is frequently occurring on roads. For this purpose, potential public transportation management strategies are as follows:

(1) By preferentially distributing eco-friendly buses, such as electric buses, to routes that pass through these areas, the impact of exhaust gas on citizen health is mitigated, even if the energy consumption is the same.

(2) Subsidies can be provided to preferentially install ISG devices on buses using fossil-based fuels that pass through these areas, reducing idling.

(3) In terms of traffic operations, exclusive bus lanes can be installed on routes where idling is frequent, reducing the idling time by improving the bus travel speed and reliability by reducing traffic delays.

Figure 5(a) shows the spatial distribution and density of idling during the day rather than the peak hour at bus stops. As shown in Fig. 5(a), idling occurred for less than $2.5 \mathrm{~h}$ in many areas, but similar to Fig. 4(a), the density of idling was higher in areas slightly to the east from the center, which have a darker color. However, in Fig. 5(b), the distribution of the cells with the highest idling density is different in the various regions based on the type of idling occurring at bus stops. Among these areas, Indexes 7, 8, and 9, where idling is frequent on roads, are areas where idling is frequent at bus stops as well. The unusual point is that, except for Indexes 7, 8, and 9, the bus stops are in the fringe areas. As shown in Table 5, the average idling time is relatively long. This is because the last stops of the public buses are in these areas, and the buses wait for a relatively long time, idling for the next operation. In these areas, as previously mentioned, the idling patterns are identical to those occurring in the depots, thus the same strategies should be applied. Specifically, the idling pattern shows a total of 676 idling occurrences in the Index-1 area where idling most frequently occurred during the day. The idling in the Index-1 area occurred for approximately $26 \mathrm{~h}$, consuming $64 \mathrm{~m}^{3}$ of CNG,

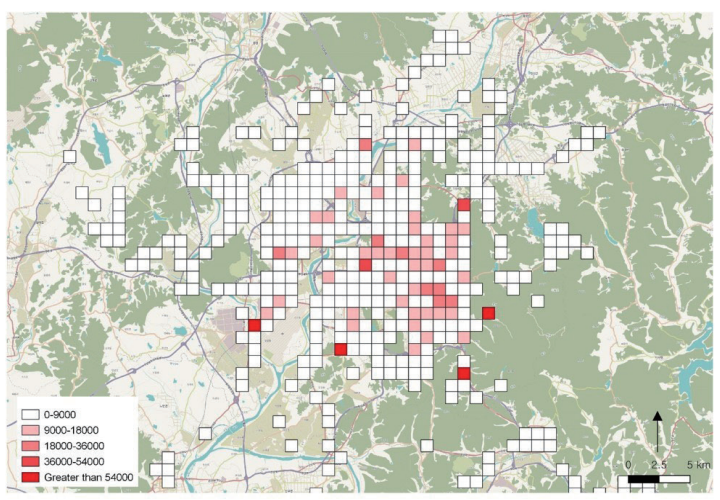

(a)

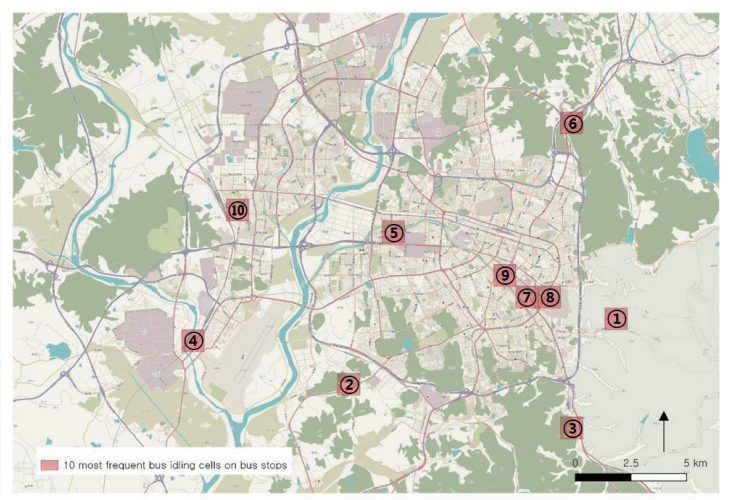

(b)

Fig. 5. (Color online) (a) Distribution and density of idling at bus stops and (b) 10 frequent idling cells at bus stops. 
Table 6

Idling characteristics, fuel uses, and exhaust emissions of 10 most frequent idling cells at bus stops for an entire day.

\begin{tabular}{|c|c|c|c|c|c|c|c|c|c|}
\hline \multirow[b]{2}{*}{ Index } & \multicolumn{3}{|c|}{ Idling characteristics } & \multicolumn{2}{|c|}{ Fuel use } & \multicolumn{4}{|c|}{ Exhaust emissions } \\
\hline & $\begin{array}{l}\text { Total idling } \\
\text { time (s) }\end{array}$ & $\begin{array}{c}\text { Number of idling } \\
\text { occurrences }\end{array}$ & $\begin{array}{c}\text { Average } \\
\text { idling time (s) }\end{array}$ & $\begin{array}{l}\mathrm{CNG} \\
\left(\mathrm{m}^{3}\right)\end{array}$ & $\begin{array}{l}\text { Cost } \\
(\$)\end{array}$ & $\begin{array}{l}\mathrm{CO}_{2} \\
(\mathrm{~kg})\end{array}$ & $\begin{array}{c}\text { THC } \\
\text { (g) }\end{array}$ & $\begin{array}{l}\mathrm{CO} \\
(\mathrm{g})\end{array}$ & $\begin{array}{c}\mathrm{NO}_{x} \\
(\mathrm{~g})\end{array}$ \\
\hline 1 & 92584 & 676 & 137 & 64 & 40 & 197 & 31 & 107 & 268 \\
\hline 2 & 79949 & 414 & 193 & 55 & 34 & 170 & 27 & 93 & 231 \\
\hline 3 & 71328 & 442 & 161 & 50 & 31 & 152 & 24 & 83 & 206 \\
\hline 4 & 56424 & 261 & 216 & 39 & 24 & 120 & 19 & 65 & 163 \\
\hline 5 & 49968 & 648 & 77 & 35 & 21 & 106 & 17 & 58 & 145 \\
\hline 6 & 40862 & 365 & 112 & 28 & 18 & 87 & 14 & 47 & 118 \\
\hline 7 & 35626 & 1346 & 26 & 25 & 15 & 76 & 12 & 41 & 103 \\
\hline 8 & 34903 & 1353 & 26 & 24 & 15 & 74 & 12 & 40 & 101 \\
\hline 9 & 28981 & 1126 & 26 & 20 & 12 & 62 & 10 & 34 & 84 \\
\hline 10 & 28691 & 335 & 86 & 20 & 12 & 61 & 10 & 33 & 83 \\
\hline
\end{tabular}

equivalent to $\$ 40$, as shown in Table 6. $\mathrm{CO}_{2}$, THC, $\mathrm{CO}$, and $\mathrm{NO}_{x}$ emissions of $197 \mathrm{~kg}, 31 \mathrm{~g}, 107 \mathrm{~g}$, and $268 \mathrm{~g}$, respectively, were generated by idling.

As can clearly be seen in Table 5, the average idling time is short when compared with that on roads in the cells near commercial and business areas, such as the Index 7, 8, and 9 cells, but the passenger demand is high and relatively more buses are operated in these areas. Therefore, it can be concluded that the total idling time is longer than those of other areas. Specifically, in these areas, the average idling time is $26 \mathrm{~s}$, whereas the average number of idling occurrences is 1275 , which is higher than those of other areas. Therefore, in these areas, it is necessary to apply traffic management strategies to reduce idling and establish management strategies for individual bus stops to mitigate adverse effects on the health of waiting passengers. Potential bus stop management strategies are as follows:

Select bus stops with high idling frequency through the spatial analysis applied in this study. According to the priority based on the results of the spatial analysis, bus shelters can be converted to eco-friendly models considering the local government budget such that the waiting passengers will be less exposed to PM and other pollutants. A previous study concluded that the impact of PM and exhausted vehicle emissions on passengers differs according to the physical shape of bus shelters. ${ }^{(18)}$ In addition, a recently developed ecofriendly bus shelter prevents the inflow of pollutants, such as PM and vehicle emissions around the bus stops, and improves the air quality at bus stops through an air purifier. ${ }^{(19)}$

\section{Conclusions}

In this study, we analyzed the temporal and spatial distributions of transit bus idling using transit bus operational information collected using a DTG. Transit bus management strategies were then proposed on the basis of the analysis results. Specifically, all idling times were calculated by analyzing the driving records of all buses operating in Gwangju for 1 day on weekdays, and the idling data were classified into depot, bus stop, and road datasets on the basis of the idling occurrence location. The classified datasets were used to analyze the idling 
characteristics and fuel consumption, and $\mathrm{CO}_{2}, \mathrm{THC}, \mathrm{CO}$, and $\mathrm{NO}_{x}$ emissions were calculated using the MOVES model.

The analysis results show that the number of idling occurrences was the highest at 12867 from 8:00 to 9:00 am, followed by 12257 from 6:00 to 7:00 pm. The longest total idling time was calculated as $183 \mathrm{~h}$ during the morning peak period of 8:00-9:00 am. The second longest idling time was calculated as approximately $174 \mathrm{~h}$ from 8:00 to 9:00 pm. The largest proportion of the total idling time was idling caused by the traffic situation on roads, accounting for $74-81 \%$ of the total. However, $12-18 \%$ of the total idling occurred at bus stops and $4-14 \%$ of the total idling occurred in depots. The $\mathrm{CNG}$ consumed by all transit buses during idling for a single day was $7402 \mathrm{~m}^{3}$, which was estimated to cost approximately $\$ 4585$.

The results of GIS analysis show that $202 \mathrm{~m}^{3}$ of CNG was consumed because of idling in depots where idling most frequently occurred. Measures need to be introduced to exclude the cost of fuel that is consumed because of unnecessary idling from the subsidies paid to bus companies. To analyze the spatial distribution and density of idling occurring on roads, the 10 areas where idling most frequently occurred on roads were identified. The potentially applicable transit bus management strategies are as follows: (1) By preferentially distributing eco-friendly buses, such as electric buses, to routes that pass through these areas, the impact of exhaust gas on citizen health can be mitigated; (2) subsidies can be provided to preferentially install ISG devices on buses using fossil-based fuels that pass through these areas, reducing idling; and (3) exclusive bus lanes can be installed on routes where idling is frequent, reducing idling time by improving the bus travel speed and reliability by reducing traffic delays. The 10 areas where idling most frequently occurred at bus stops were also identified to apply the following management strategy. The bus shelters in these areas can be converted to ecofriendly models considering the local government budget such that the waiting passengers will be less exposed to PM and other pollutants.

\section{Acknowledgments}

This research was supported by the Basic Science Research Program through the National Research Foundation of Korea (NRF), funded by the Ministry of Science, ICT \& Future Planning (NRF-2017R1A2B1009966).

\section{References}

1 C. Ma and X. Yang: 19th COTA Int. Conf. Transp. Prof. (ASCE, 2019) 4060. https://doi. org/10.1061/9780784482292.351

2 J. Kinsey, D. Williams, Y. Dong, and R. Logan: Environ. Sci. Technol. 41 (2007) 4972. https://doi.org/10.1021/ es0625024

3 Q. Zhang, H. J. Fischer, R. E. Weiss, and Y. Zhu: Atmos. Environ. 69 (2013) 65. https://doi.org/10.1016/ j.atmosenv.2012.12.015

4 H. Omidvarborna, A. Kumar, and D. S. Kim: J. Environ. Chem. Eng. 2 (2014) 2335. https://doi.org/10.1016/ j.jece.2014.09.020

5 R. L. McCormick, M. S. Graboski, T. L. Alleman, and J. Yanowitz: J. Air Waste Manage. Assoc. 50 (2000) 1992. https://doi.org/10.1080/10473289.2000.10464229

6 K. Shandilya and A. Kumar: Environ. Prog. Sustainable Energy 32 (2013) 1134. https://doi.org/10.1002/ ep.11696 
7 L. Yong-chen and S. Li: 2011 Int. Conf. Mechatronic Sci., Electr. Eng. Comput. (MEC) (IEEE, 2011) 763. https://doi.org/10.1109/MEC.2011.6025576

8 D. Huang and R. He: 2010 Int. Conf. Comput. Control Ind. Eng. (IEEE, 2010) 212. https://doi.org/10.1109/ CCIE. 2010.62

9 E. Ziring and P. Sriraj: Transp. Res. Rec. 2143 (2010) 142. https://doi.org/10.3141/2143-18

10 Y. Y. Lee, S. L. Lin, R. Aniza, and C. S. Yuan: Aerosol Air Qual. Res. 17 (2017) 2424. https://doi.org/10.4290/ aaqr.2017.09.0301

11 Ministry of Land, Infrastruct. Transport of South Korea: Digital Tachograph FAQ (Ministry of Land, Infrastructure and Transport of South Korea, Seoul, 2017) p. 1.

12 Google Maps: https://www.google.com/maps/ (accessed July 2019).

13 kakaomap: https://map.kakao.com/ (accessed July 2019).

14 US EPA, MOVES2014a User Guide (US EPA, 2015).

15 Wikipedia: https://en.wikipedia.org/wiki/Gwangju (accessed July 2019).

16 L. Gaines, E. Rask, and G. Keller: Transportation Research Board 92nd Annual Meeting (National Academy of Sciences, 2013) 13-4606.

17 Ministry of Land, Infrastructure and Transport of South Korea: Guidelines for Evaluating Transportation Facilities (Ministry of Land, Infrastructure and Transport of South Korea, Seoul, 2017) p. 207.

18 G. Park, W. Do, and E. Yoo: Reduction of Air Pollutants Through Facility Improvement of Bus Platform and Risk Assessment (Busan Metropolitan City Institue of Health \& Environment, Busan, 2011) p. 163.

19 etoday: http://www.etoday.co.kr/news/section/newsview.php?idxno=1747275 2019 (accessed July 2019). 